American Journal of Environmental Sciences 7 (3): 254-262, 2011

ISSN 1553-345X

(C) 2011 Science Publications

\title{
Physicochemical and Microbial Caracteristics Performency in Wastewater Treated Under Aerobic Reactor
}

\author{
Asma Ben Rajeb, Hamadi Kallali, Neila Saidi, Samira Abidi, \\ Naceur Jedidi and Abdennaceur Hassen \\ Wastewater Treatment Laboratory, Water Research and Technologies, \\ Route Touristique De Soliman, P.O.Box 273, 8020 Soliman, Tunisia
}

\begin{abstract}
Problem statement: The current work study the efficiency of biological wastewater treatment by an aerobic reactor which could be used in small agglomerations. RBC reduced physicochemical and microbiological load of wastewater but values remain above Tunisian standard. Approach: Experiments were conducted on a sand filled PVC column fed with wastewater treated by Rotating Biological Contactor (RBC) at a pulsed rhythm of 8 sequences per day. For performances study process, physicochemical and bacterial analyses effluent at inlet and outlet of column were realized. Results: The results showed that through filter mass $(\mathrm{D} 10=0.55 \mathrm{~mm}, \mathrm{D} 60=1.3 \mathrm{~mm}$ and coefficient uniformity $=2.36$ ) $96 \%$ of suspended solids, $99 \%$ of $\mathrm{NH}_{4}{ }^{+}-\mathrm{N}$ (during first phase), $92 \%$ of $\mathrm{COD}, 91 \%$ of $\mathrm{BOD}_{5}$ and $46 \%$ of phosphorus are retained by surface filtration. The microbial abatement results is $<1.6 \mathrm{Log}$ units of indicators fecal contamination (fecal coliforms, fecal streptococci and E. coli). The microbial water quality is slightly higher than Tunisian standards. The removal of microbial indicators in the considered reactor depends on the depth of the filter and negatively correlated with $\mathrm{NO}_{3}{ }^{-} \mathrm{N} \quad(\mathrm{r}=-0.99$, with $E$. coli at 3rd OPD). Conclusion/Recommendation: Results confirmed that the reactor tested is performed as an advanced treatment system for $\mathrm{DBO}, \mathrm{COD}, \mathrm{SS}, \mathrm{NH}_{4}{ }^{-}-\mathrm{N}$ and $\mathrm{NO}_{3}{ }^{-} \mathrm{N}$. Despite that $96 \%$ of SS efficiency reduction, clogging is not achieved quickly that due to biofilm detachment phenomena. The removal of microbial indicators in the considered reactor depends on the depth of the filter and negatively correlated with $\mathrm{NO}_{3}{ }^{-} \mathrm{N}$. Disinfection performances for the considered reactor reduce microbial load, however chlore, ozone or UV disinfection should be considered.
\end{abstract}

Key words: Aerobic reactor, pulsed rhythm, bacterial analyses, Rotating Biological Contactor (RBC), physicochemical parameters, Chemical Oxygen Demand (COD), Suspended Solids (SS), Biological Oxygen Demand $\left(\mathrm{BOD}_{5}\right)$, Scanning Electron Microscope (SEM), wastewater treated, microbial caracteristics

\section{INTRODUCTION}

Tunisia is in water deficiency country because it is quite low availability compared to international standards (Mediterranean Water Scarcity and Drought Report, 2006). This situation will become more critical in the coming decades, with expand water demand. For this, politic Tunisian turned in recycling and reuse treated wastewater. The estimated quantity of treated wastewater reused for irrigated areas is 21 million $\mathrm{m}^{3}$ in 2009 estimate to 73 million $\mathrm{m}^{3}$ in 2014 (National Sanitation Utility, 2009). However, the reuse of treated water is accompanied by sanitary and environmental risks (Guidelines for managed aquifer recharge, 2009). The aerated biofilter process appears to be well suited to the requirements of small wastewater treatment plant (Boller, 1997). It combines aeration and clarification in one unit by using an inert support material for both biofilm attachment and filtration. Removal rates become independent of clarification and sludge settles ability limits (Doan and Lohi, 2009), whereas concentration of biomass is increased. The performance of the aerated biofilter process has been proven to be an effective process for treating domestic effluent. By using granular media, the aerated biofilter can be operated at high organic loading rate.

In general, rotating biological contactor decrease physicochemical (Doan and Lohi, 2009) and microbiological load with important efficiency. Although wastewater treated by $\mathrm{RBC}$ have $\mathrm{BOD}_{5}$, COD, suspended solids, $\mathrm{NO}_{3}^{-}, \mathrm{NO}_{2}^{-}$, phosphorus and fecal pollution indicators bacteria remains above

Corresponding author: Neila Saidi, Wastewater Treatment Laboratory, Water Research and Technologies, Route Touristique De Soliman, P.O.Box 273, 8020 Soliman, Tunisia Tel: +216-79325044 
Tunisian standard for irrigation or discharge. Tertiary treatment is necessary for that we installed an aerobic reactor in output of RBC. This work goal is to study the efficiency of aerobic treatment and to correlation between microbiological and physic-chemical parameters.

\section{MATERIAL AND METHODS}

Experimental setup: A PVC column of $40 \mathrm{~cm}$ diameter and $220 \mathrm{~cm}$ height, filled with $150 \mathrm{~cm}$ sand, has been installed after a semi-industrial Rotating Biological Contactor (RBC) wastewater treatment plant (Fig. 1). The filling sand have a homogeneous grain size distribution $\left(\mathrm{d}_{10}=0.55 \mathrm{~mm}, \mathrm{~d}_{60}=1.3 \mathrm{~mm}\right.$ and an uniformity coefficient, $\mathrm{UC}=2.36$ ). The X-ray diffractometer analysis showed that the sand is exclusively constituted by quartz $(90 \%)$ and a small proportion of calcite. The column is equipped with four water samples (S1-S4) at 30, 60, 90 and $120 \mathrm{~cm}$, respectively. The column was continuously fed at a hydraulic loading rate of $50 \mathrm{~cm} \mathrm{day}{ }^{-1}$ supplied in 8 sequences which corresponds to 63 liters per day and around 8 liters by pulse. The column has been operated until it cannot infiltrate the daily hydraulic load due to total clogging.

Methods: Performances of the aerobic reactor have been investigated during a period of 111 days. Samples were analyzed for Chemical Oxygen Demand (COD), Suspended Solids (SS), Biological Oxygen Demand $\left(\mathrm{BOD}_{5}\right)$, Total Kjeldhal Nitrogen (TKN), ammonium $\left(\mathrm{NH}_{4}{ }^{+} \mathrm{N}\right)$, Nitrate $\left(\mathrm{NO}_{3}{ }^{-} \mathrm{N}\right)$ and total phosphorus (TP) according to the methods prescribed in AFNOR (1992) handbook.

Fecal pollution indicators bacteria enumeration: The microbial soil contents is assessed by enumeration of faecal pollution indicators bacteria (faecal coliforms, faecal streptococci and Escherichia coli) using the most probable number method (Rodier, 1978).

Biofilm expansion observation by SEM: The soil matrix microbial biomass evolution has (SEM) been observed by scanning electron microscope and photo sequences in order to detect the biofilm progress after wastewater supply (Ibrahim et al., 2010; Mutlu, 2009).

Statistical procedures: Pearson's correlation coefficient (r) was used to show correlation between the all parameters data using Statistical Package for the Social Sciences (SPSS) software (SPSS for Windows, SPSS Inc., Chicago, Il, USA).

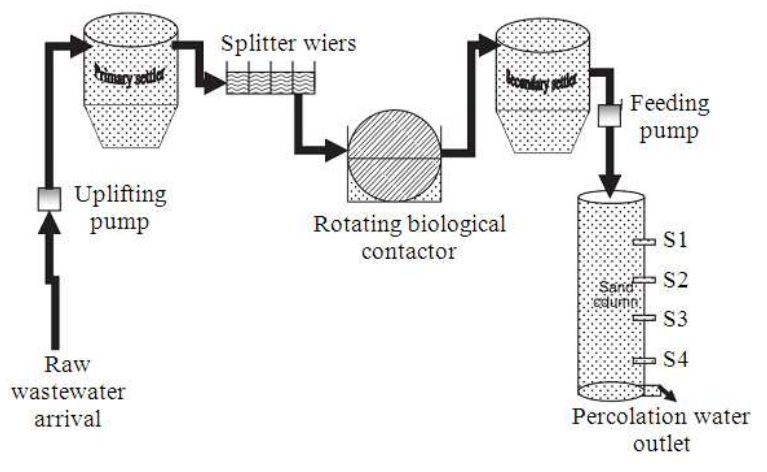

Fig. 1: Schematic of the experimental facility. S1, S2, S3, S4 water samples located at 30, 60, 90 and $120 \mathrm{~cm}$ of depth respectively

\section{RESULTS}

\section{Physicochemical parameters:}

Suspended solids removal: The $150 \mathrm{~cm}$ thickness of considered reactor ensures a significant suspended solids reduction in treated wastewater reached $96 \%$, compared to those recorded on outlet of secondary settling tank. The results obtained show SS concentrations fluctuations of effluent at outlet of column (Fig. 2a), which varies from 40 and $110 \mathrm{mg} \mathrm{L}^{-1}$ on 17th and 97th operating day (OPD) respectively. These fluctuations are generally due to dysfunction of secondary settler and SS fluctuation in raw wastewater at station outlet. Curve showed two phases based on clogging apparition.

During the first phase (ranging between 0-66th OPD), the SS retention is positively influenced by depth of filter bed. At 30, 60, 90, 120 and $150 \mathrm{~cm}$ of depth SS has a value of $38.3,45.6,50,59$ and $73 \%$ respectively on 10th OPD. SS removal is proportional to depth with sand coarse $(\mathrm{U}=2.36)$.

During the second phase, the SS removal of treated wastewater at outlet of first sample (located $30 \mathrm{~cm}$ from solid surface) was much higher (96\%) than that obtained at outlet of column $(62.5 \%)$.

COD removal: At $150 \mathrm{~cm}$ of depth, COD removal during OPD varies between 35 and $65 \%$ (Fig. 3a) in first phase (0-66th OPD) and exceeds 92\% during second phase (66-111th OPD). Following biofilm installation (installed from 66th OPD and observed by Screening Electron Microscope), COD residual range between 7.2 and $57 \mathrm{mg} \mathrm{O}_{2} \mathrm{~L}^{-1}$ (Fig. 2b) and corresponds to low biodegradable fraction (Rezaee et al., 2008). 


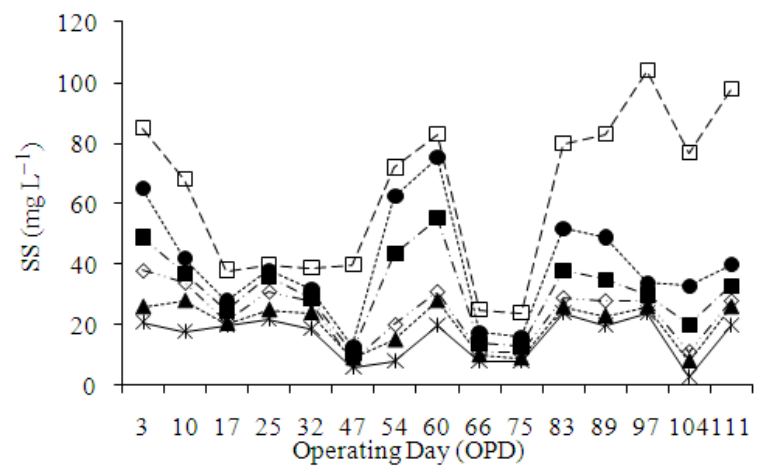

(a)

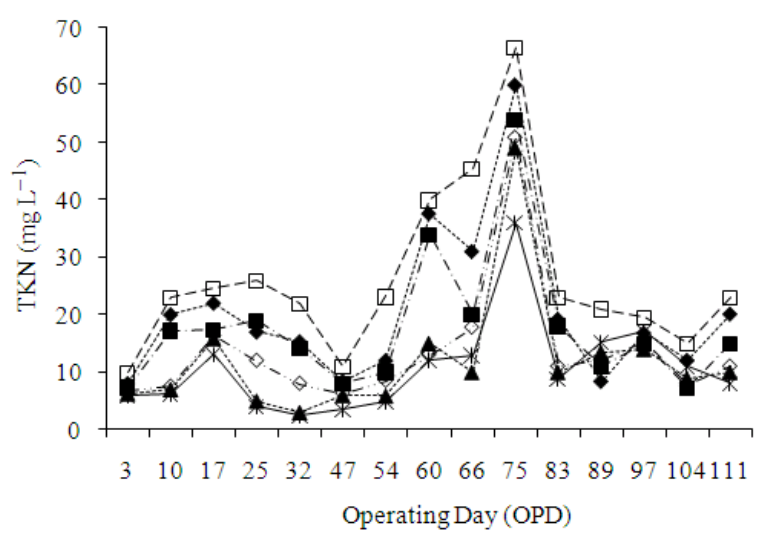

(c)

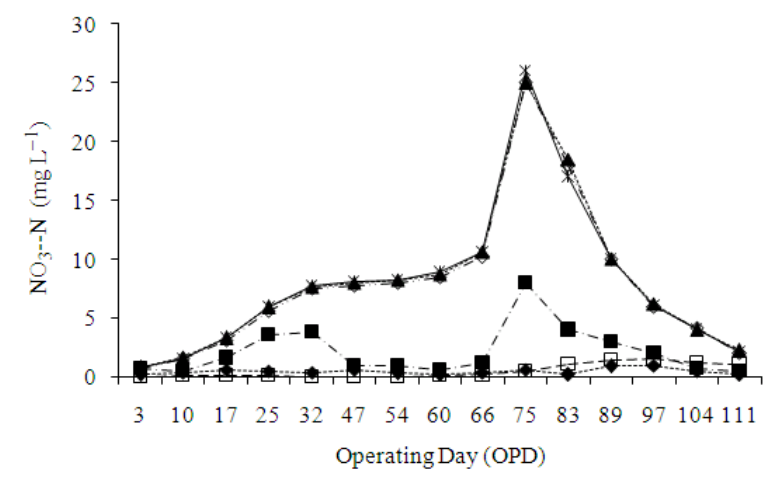

(e)

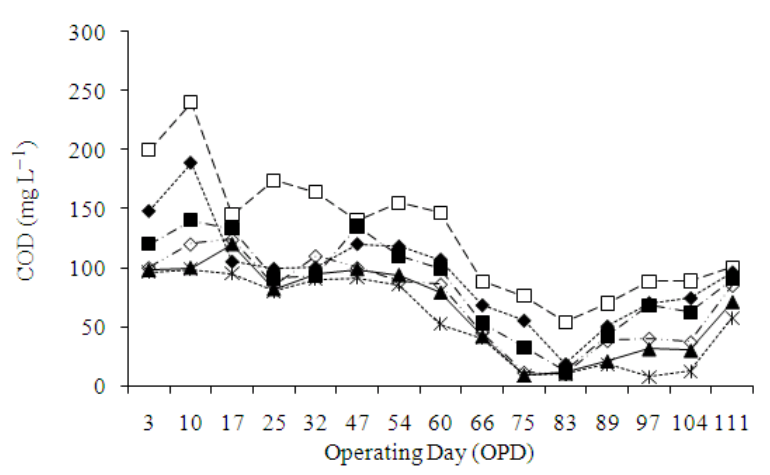

(b)

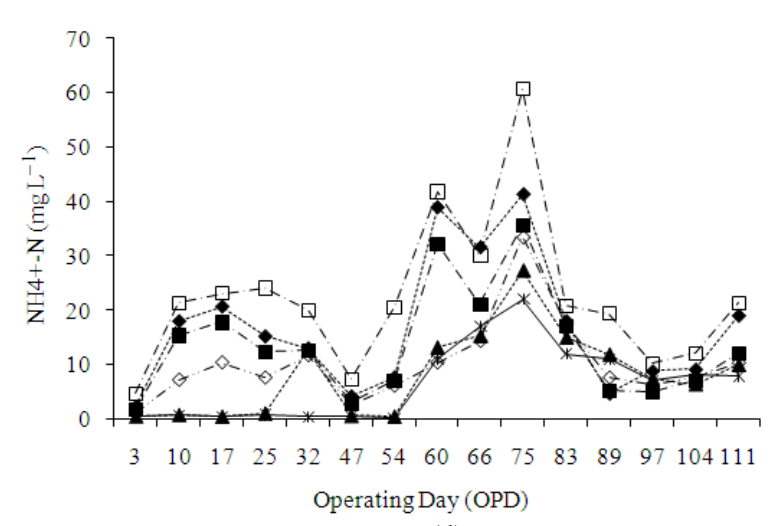

(d)

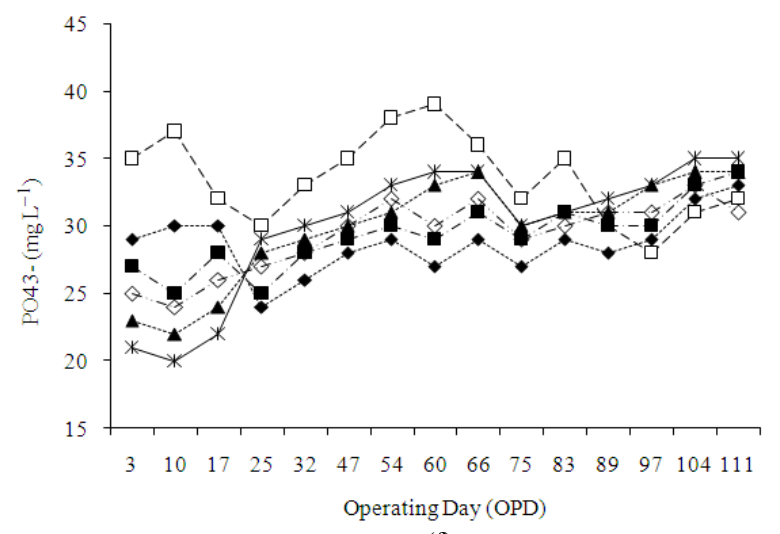

(f)

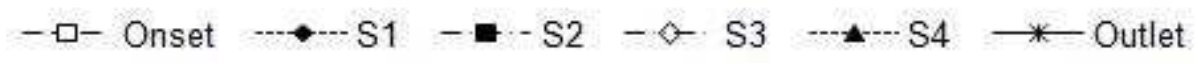

Fig. 2: Suspended solids (a), COD (b), TKN (c), $\mathrm{NH}_{4}{ }^{+}$(d), $\mathrm{NO}_{3}{ }^{-}$(e) and phosphorus (f) evolution during OPD at onset and outlet of column and four water samples (S1, S2, S3 and S4)

COD decreases even more as depth increases (Fig. 2b). At 30, 60, 90, 120 and $150 \mathrm{~cm}$ of depth COD have a value of $29,40,46,70$ and $74 \%$ respectively on 89 th OPD. However, following the biofilm installation effectiveness of purifying considered reactor, COD removal is higher than $90 \mathrm{~cm}\left(10 \mathrm{mg} \mathrm{L}^{-1} \mathrm{COD}\right.$ at $83 \mathrm{rd}$ OPD with $81 \%$ of reduction) has $150 \mathrm{~cm}$ depth $(9 \mathrm{mg}$ $\mathrm{L}^{-1} \mathrm{COD}$ at 83 rd OPD with $83 \%$ of reduction) than that obtained at $30 \mathrm{~cm}$ of depth $\left(18 \mathrm{mg} \mathrm{L}^{-1} \mathrm{COD}\right.$ at $83 \mathrm{rd}$ OPD with $67 \%$ of reduction). However $90 \mathrm{~cm}$ of filter 
bed is necessary for COD reduce. At outlet of column, COD value does not exceed $90 \mathrm{mg} \mathrm{L}^{-1}$ during the second phase (66-111th OPD) and is conformed to standards Tunisian NT.106.02 rejection.

BOD removal: The purifying performance of considered reactor in terms of $\mathrm{BOD}_{5}$ removal during operating days (Fig. 3b) showed a high performance at outlet of column. At $150 \mathrm{~cm}$ of depth, $91 \%$ of the $\mathrm{BOD}_{5}$ to be removed following biomass installation and clogging apparition during the second phase of OPD. $\mathrm{BOD}_{5}$ decreases even more as depth increases, for example at 104th OPD with $30,60,90,120$ and $150 \mathrm{~cm}$ of depth $\mathrm{BOD}_{5}$ have a value of $29,46,64,71$ and $86 \%$ respectively.

Nitrogen removal: The results obtained showed that TKN concentrations fluctuations at outlet of column (Fig. 2c), which varying from 2.5 and $36 \mathrm{mg} \mathrm{L}^{-1}$ during OPD. At outlet of column $(150 \mathrm{~cm}$ of depth), TKN obtained during the first phase of OPD was $89 \%$ of nitrate transformation. Then TKN does not exceed 71\% of nitrate transformation during the second phase of OPD. At $111^{\text {th }}$ OPD with $30,60,90,120$ and $150 \mathrm{~cm}$ of depth TKN have a value of 7, 32, 46, 60 and $64 \%$ respectively.

At 54th OPD, an important $\mathrm{NH}_{4}{ }^{+}-\mathrm{N}$ reduction (Fig. 2d) observed reach $0.23 \mathrm{mg} \mathrm{L}^{-1}$ value conformed to standards Tunisian NT.106.02 rejection $\left(1 \mathrm{mg} \mathrm{L}^{-1}\right)$.

Biofilm installation and biomass development at 89th OPD decreases nitrification by preventing oxygen diffusion inside filter bed; this produces $\mathrm{NO}_{3}{ }^{-} \mathrm{N}$ concentrations drop of treated wastewater, passed from 1.5-26 mg L $\mathrm{m}^{-1}$ at 10th-75th OPD respectively (Fig. 2e). At 75th OPD with 30, 60, 90, 120 and $150 \mathrm{~cm}$ of depth $\mathrm{NO}_{3}{ }^{-} \mathrm{N}$ have a value of $0.6,8,25,25$ and $26 \mathrm{mg} \mathrm{L}^{-1}$ respectively. This agrees with results found by Cha et al. (2005) which indicates a significant fraction of ammonia nitrogen is fixed in first centimeters of filer bed. Nevertheless, at outlet of column, treated wastewater does not exceed $26 \mathrm{mg} \mathrm{L}^{-1}$ it's conformed to standards Tunisian NT.106.02 rejection $\left(50 \mathrm{mg} \mathrm{L}^{-1}\right)$.

Phosphorus removal: Phosphorus removal from wastewater is attributed to various phenomena such as adsorption, precipitation and/or assimilation by microorganisms. Orthophosphate concentrations in treated wastewater from the different sampler's column were shown in Fig. 2f. Three phases were observed.

During the first phase (0-25th OPD), the results showed the most important decrease of orthophosphate during OPD with $46 \%$ of reduction. Phosphorus removal from treated wastewater is proportional to the filter bed depth. . At $10^{\text {th }}$ OPD with 30, 60, 90, 120 and $150 \mathrm{~cm}$ of depth orthophosphates have a value of 19 , $32,35,41$ and $46 \%$ respectively.

During the second phase (25-89th OPD), leaching phosphorus within filter bed is realized. Then efficiency of phosphorus removal does not exceed $13 \%$ of reduction at 60th OPD.

During the third phase (starting at 89th OPD), organic phosphorus fixed in first operation weeks is throw back outlet column by delivering phosphorus accumulated in bacteria. For example, at 97th OPD phosphorus concentration is $28 \mathrm{mg} \mathrm{L}^{-1}$ in onset of column increased to $33 \mathrm{mg} \mathrm{L}^{-1}$ in outlet of column. This phenomena is due to the $\mathrm{pH}$ decrease and redox potential associated with nitrates and oxygen consumption by bacteria.

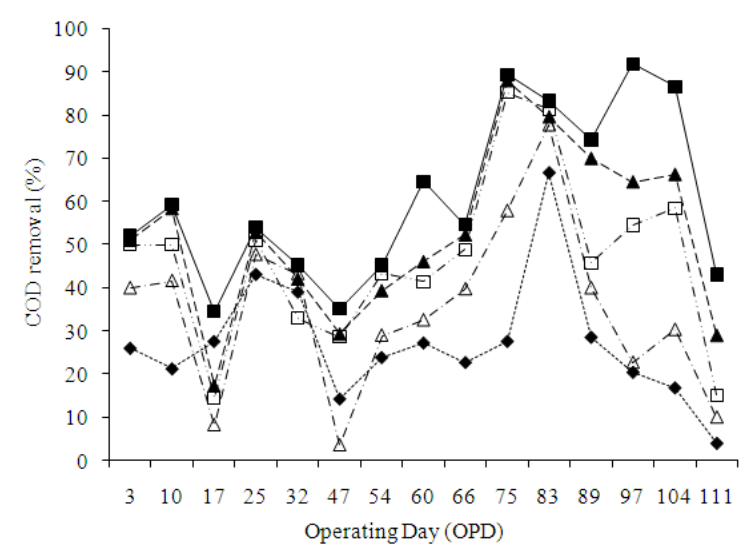

(a)

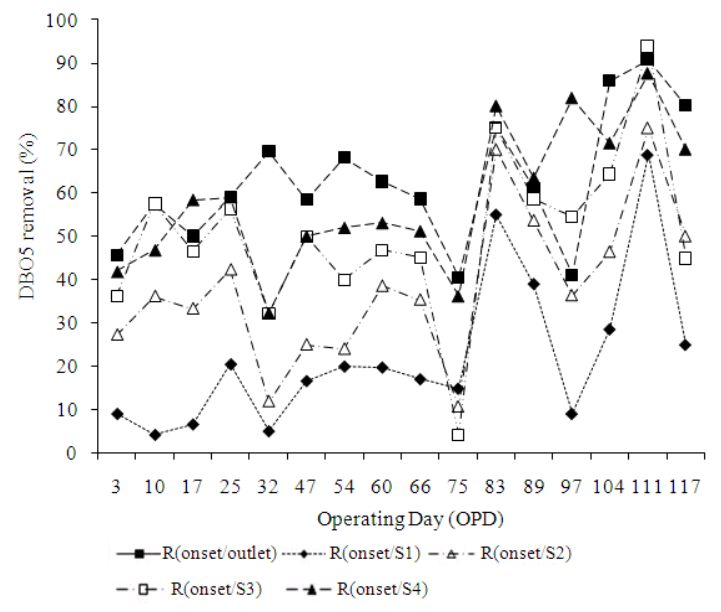

(b)

Fig. 3: Evolution of filter bed performance in terms COD (a) and $\mathrm{DBO}_{5}$ (b) reduction (\%) between onset and outlet of column and between onset of column and four water samplers respectively $\mathrm{S} 1$, $\mathrm{S} 2, \mathrm{~S} 3$ and S4 


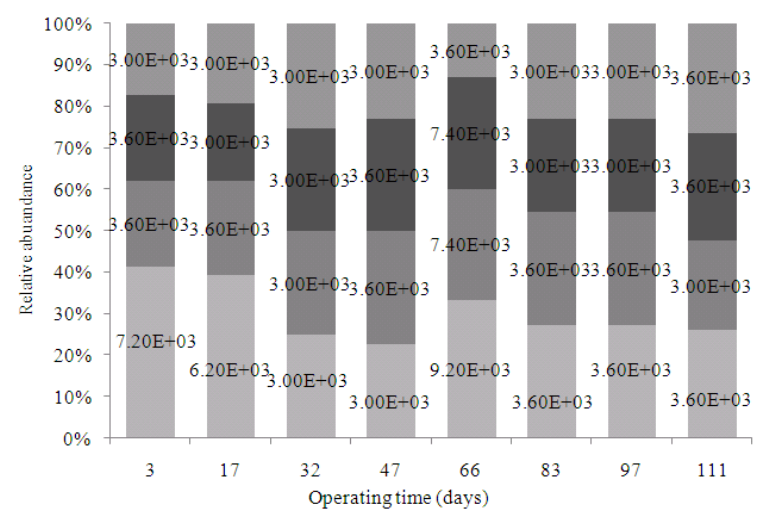

(a)

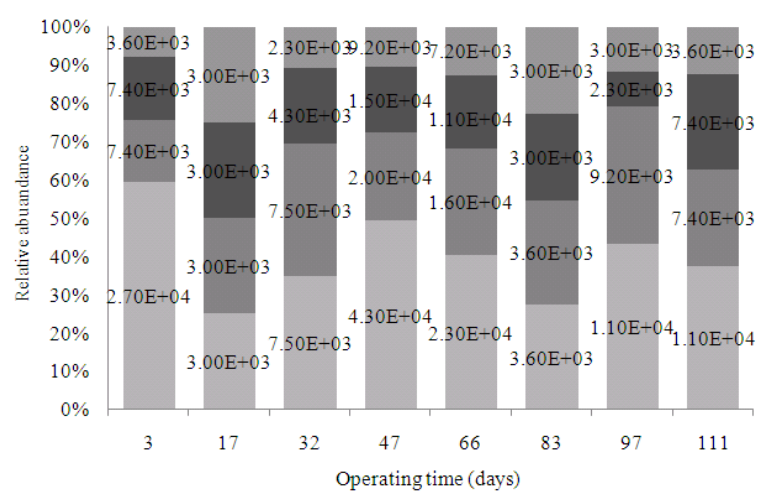

(b)

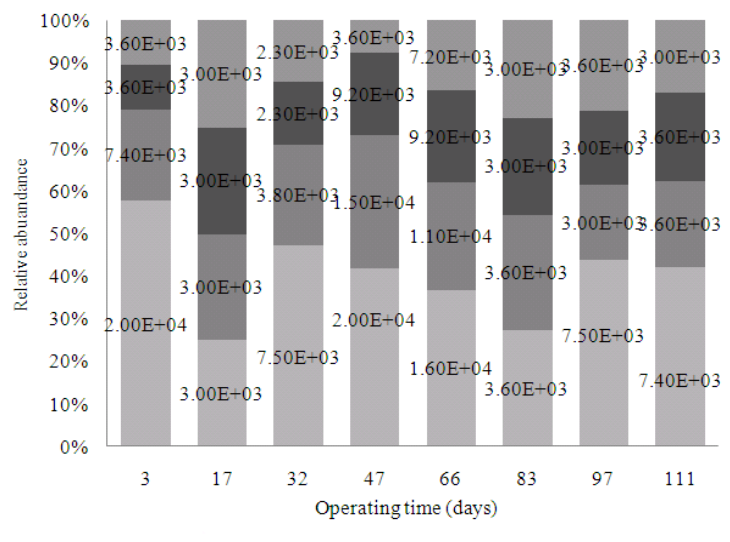

(c)

Fig. 4: Abundance and enumeration of (a) faecal streptococci, (b) faecal coliforms and (c) Escherichia coli in four water samples (S1-S4) at $30,60,90$ and $120 \mathrm{~cm}$, respectively

Disinfection performances: Disinfection performances mean the indicators of fecal contamination (fecal coliforms, fecal streptococci and Escherichia coli) in different depths $(30,60,90$ and $120 \mathrm{~cm})$ and increasing time of the filters are showed in Fig. 4.

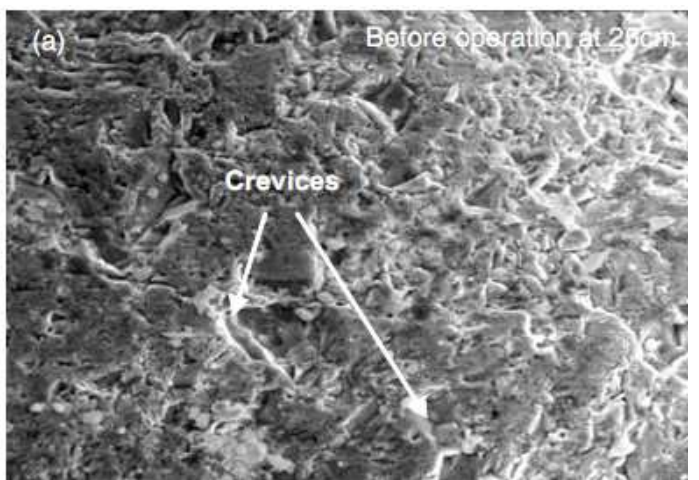

(a)

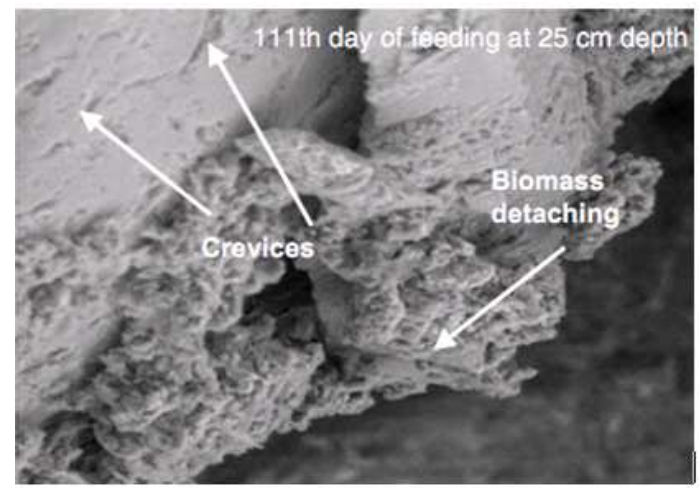

(b)

Fig. 5: Illustration (400x) of the sand grain surface sampled at $25 \mathrm{~cm}$ (a) before operation and (b) 111 OPDs

At 47th OPD and on $30 \mathrm{~cm}$ of depth, the values of faecal streptococci reduction increased compared to values obtained at the beginning of OPD $\left(7.210^{3}-310^{3}\right.$ MPN/100 mL). This bacterial reduction is strengthened by adsorption fecal streptococci on organic matter and submersion appeared an increased value with filter bed depth purifying quality, the relative abundance passed from $40-20 \%$ of total fecal streptococci (Fig. 4a).

Fecal coliforms are eliminated as fecal streptococci (Fig. 4b). Faecal coliforms effective removal was observed after submersion at 66th OPD with a relative abundance of $50 \%$ of total fecal coliforms.

Then oxygen supply decreases towards 83rd OPD, effectiveness of fecal coliforms reduction decreases with an abundance of $25 \%$ of total fecal coliforms. Escherichia coli are similar to fecal coliforms reduction (Fig. 4 c). The treatment is more efficient at $66^{\text {th }}$ OPD and outlet of column (0.56 log unit). At outlet of column with $150 \mathrm{~cm}$ of depth $1.36 \mathrm{log}$ unit reductions for fecal coliforms and E. coli is registered. Although aeration provided to our system with hydraulic loading rate applied in 8 pulses, may eliminated fecal indicators bacteria. 
Biomass detaching obtained (Rajeb et al., 2009) at 111th OPD when biofilm was observed by Scanning Electron Microscope (SEM), this detaching has been boosted by the coarse sand used (Fig. 5). At the 111th OPD, the soil matrix observation at $25 \mathrm{~cm}$ revealed detachment of the biomass with crevices reappearance on the sand grain surface.

Wastewater qualities: We choose some representative time during OPD (3rd, 66th and 111th) showed in Table 1. The process has a high performance in terms of SS $(80 \%), \mathrm{BOD}_{5}(91.6 \%)$ at 111 th OPD, but COD and $\mathrm{NO}_{3}{ }^{-} \mathrm{N}, \mathrm{NH}_{4}{ }^{+} \mathrm{N}$ present an average performance respectively 43,49 and $62.4 \%$. Nevertheless, at outlet of column, treated wastewater it's conformed to standards Tunisian NT.106.02 rejection.

In treated wastewater phosphorus content (34.66 $\mathrm{mg} \mathrm{L^{-1 }}$ ) remains superior to Tunisian standard NT 106.02. For indicators of fecal contamination, 78.5\% fecal coliforms and $81.2 \%$ Escherichia coli were removed. Despite the significant efficiency obtained at outlet of column the microbial water quality is slightly higher than Tunisian standards. Tertiary treatment application must be envisaged.
Correlation between physicochemical and microbial caracteristics: The statistical SPSS software was used to determine correlations between physicochemical and microbial characteristics. Table 2 indicates (r) coefficients estimated by Pearson correlation significant test for several different physicochemical parameters and indicators of fecal contamination (fecal coliforms, fecal streptococci and E. coli).

Generally positive correlations between the microbiological and physicochemical parameters were observed, with the exception of nitrate which showed a negative correlation. At 3rd OPD, a statistical significance was showed at $\mathrm{p}<0.01$ for the considered reactor. We obtained a highly significant, positively correlated $(\mathrm{r}=0.94,0.98,0.94,0.96,0.96$ and 0.94$)$ relationship between $\mathrm{SS}, \mathrm{COD}, \mathrm{BOD}_{5}, \mathrm{TKN}, \mathrm{NH}_{4}{ }^{+}-\mathrm{N}$, $\mathrm{P}$ and fecal streptococci. Whereas negatively correlated relationships were obtained between $\mathrm{NO}_{3}{ }^{-} \mathrm{N}$ and fecal streptococci $(r=-0.98)$. At 111th OPD, we observed no significant difference between physicochemical parameters (COD, $\mathrm{TKN}, \mathrm{NH}_{4}{ }^{-}-\mathrm{N}, \mathrm{NO}_{3}{ }^{-} \mathrm{-N}$ and $\left.\mathrm{P}\right)$ and fecal streptococci $(\mathrm{p}>0.05)$.

Table 1: Different parameter efficiency during 3rd, 66th and 111th

\begin{tabular}{|c|c|c|c|c|c|c|c|c|c|c|}
\hline & \multicolumn{3}{|l|}{ 3rd OPD } & \multicolumn{3}{|l|}{$66^{\text {th }}$ OPD } & \multicolumn{3}{|l|}{$111^{\text {th }}$ OPD } & \multirow[b]{2}{*}{$\begin{array}{l}\text { Standards } \\
\text { Tunisian }\end{array}$} \\
\hline & $\begin{array}{l}\text { Onset of } \\
\text { column }\end{array}$ & $\begin{array}{l}\text { Outlet of } \\
\text { column }\end{array}$ & $(\%)$ & $\begin{array}{l}\text { Onset of } \\
\text { column }\end{array}$ & $\begin{array}{l}\text { Outlet of } \\
\text { column }\end{array}$ & $(\%)$ & $\begin{array}{l}\text { Onset of } \\
\text { column }\end{array}$ & $\begin{array}{l}\text { Outlet of } \\
\text { column }\end{array}$ & $(\%)$ & \\
\hline SS (mg/l) & $86 \pm 1$ & $20.6 \pm 0.57$ & 76.0 & $26 \pm 1$ & $7.66 \pm 0.6$ & 70.5 & $98.66 \pm 1.5$ & $20 \pm 1$ & 80.0 & 30 \\
\hline $\mathrm{COD}\left(\mathrm{mg} \mathrm{O}_{2} / \mathrm{l}\right)$ & $199 \pm 1.15$ & $95.6 \pm 0.57$ & 52.0 & $87 \pm 1$ & $40.33 \pm 0.57$ & 53.6 & $99.6 \pm 0.57$ & $57 \pm 1$ & 43.0 & 90 \\
\hline $\mathrm{DBO}_{5}\left(\mathrm{mg} \mathrm{O}_{2} / \mathrm{l}\right)$ & $53.6 \pm 1.52$ & $31 \pm 1$ & 42.2 & $82 \pm 1$ & $33 \pm 1$ & 61 & $31.6 \pm 0.57$ & $2.66 \pm 0.57$ & 91.6 & 30 \\
\hline $\mathrm{NH}_{4}{ }^{+}-\mathrm{N}(\mathrm{mg} / \mathrm{l})$ & $4.6 \pm 0.01$ & $0.51 \pm 0.01$ & 89.0 & $30.3 \pm 0.657$ & $17.06 \pm 0.11$ & 43.7 & $21.35 \pm 0.13$ & $8.03 \pm 0.057$ & 62.4 & 30 \\
\hline $\mathrm{NO}_{3}^{-}-\mathrm{N}(\mathrm{mg} / \mathrm{l})$ & 0 & $0.76 \pm 0.05$ & 76.0 & $0.2 \pm 0.01$ & $10.5 \pm 0.1$ & 98 & $1.1 \pm 0.01$ & $2.13 \pm 0.057$ & 49.0 & 90 \\
\hline $\mathrm{TP}(\mathrm{mg} / \mathrm{l})$ & $35.3 \pm 0.57$ & $20.6 \pm 0.57$ & 41.5 & $36 \pm 0.57$ & $34 \pm 1$ & 5.5 & $31.6 \pm 0.57$ & $34.66 \pm 0.57$ & & 0.1 \\
\hline F.C (B/100 ml $)$ & $1.110^{5} \pm 1.610^{4}$ & $3.110^{3} \pm 3.410^{2}$ & 97.0 & $1.310^{4} \pm 4.610^{3}$ & $6.6710^{3} \pm 8.0810^{3}$ & 84.6 & $1.410^{4} \pm 0$ & $310^{3} \pm 0$ & 78.5 & 2000 \\
\hline F.S $(\mathrm{B} / 100 \mathrm{ml})$ & $1.110^{4} \pm 0$ & $310^{3} \pm 0$ & 72.7 & $1.510^{4} \pm 0$ & $3.210^{3} \pm 3.4610^{2}$ & 78.6 & $810^{3} \pm 1.0410^{2}$ & $3.210^{3} \pm 3.4610^{2}$ & 60.0 & 1000 \\
\hline E. coli $(B / 100 \mathrm{ml})$ & $2.4710^{4} \pm 410^{3}$ & $3.610^{3} \pm 0$ & 85.4 & $4.510^{4} \pm 1.710^{3}$ & $210^{3} \pm 0$ & 95.5 & $1.610^{3} \pm 3.4610^{2}$ & $3.210^{3} \pm 3.4610^{2}$ & 81.2 & - \\
\hline
\end{tabular}

*Values present the average of three replicates; $\eta$ : indicate efficiency of different parameters calculated by (onset parameter-outlet parameter/onset parameter) $\times 100$; F.C: fecal coliforms; F.S: fecal streptococci; E. coli: Escherichia coli; SS: Suspended Solid; COD: chemical oxygen demand; $\mathrm{BOD}_{5}$ : biological oxygen demand; TKN: Total Kjeldhal Nitrogen; $\mathrm{NH}_{4}{ }^{+}-\mathrm{N}$ : ammonium; $\mathrm{NO}_{3}{ }^{-}-\mathrm{N}$ : Nitrate; TP: Total Phosphorus

Table 2: Correlation (r) coefficients between physicochemical and microbial characteristics

Pearson correlation

\begin{tabular}{|c|c|c|c|c|c|c|c|c|c|}
\hline & \multicolumn{3}{|l|}{$3 \mathrm{rd}$} & \multicolumn{3}{|l|}{47 th } & \multicolumn{3}{|l|}{ 111th } \\
\hline & F.C & F.S & E. coli & F.C & F.S & E. coli & F.C & F.S & E. coli \\
\hline $\mathrm{SS}$ & $0.854^{*}$ & $0.940^{* *}$ & $0.953^{* *}$ & 0.687 & $0.927^{* *}$ & 0.648 & $0.856^{*}$ & $0.972^{* *}$ & $0.975^{* *}$ \\
\hline $\mathrm{COD}$ & $0.946^{* *}$ & $0.985^{* *}$ & $0.978^{* * *}$ & $0.894^{*}$ & 0.808 & $0.872^{*}$ & $0.923^{* *}$ & 0.553 & 0.694 \\
\hline $\mathrm{BOD}_{5}$ & $0.823^{*}$ & $0.942^{* *}$ & $0.974^{* *}$ & 0.71 & $0.869^{*}$ & 0.684 & $0.833^{*}$ & $0.946^{* *}$ & $0.970^{* *}$ \\
\hline TKN & $0.934^{* *}$ & $0.967^{* *}$ & $0.945^{* *}$ & $0.937^{* *}$ & 0.712 & $0.921^{* *}$ & $0.964^{* * *}$ & 0.716 & $0.890^{*}$ \\
\hline $\mathrm{NH} 4^{+}-\mathrm{N}$ & $0.947^{* *}$ & $0.962^{* *}$ & $0.939^{* *}$ & $0.911^{*}$ & 0.702 & $0.897^{*}$ & $0.952^{* *}$ & 0.751 & $0.919^{* *}$ \\
\hline $\mathrm{NO}^{-}-\mathrm{N}$ & $-0.869^{*}$ & $-0.980^{* *}$ & $-0.991^{* *}$ & -0.529 & $-0.988^{* * *}$ & -0.492 & -0.666 & -0.122 & -0.416 \\
\hline $\mathrm{TP}$ & $0.896^{*}$ & $0.941^{* *}$ & $0.931^{* *}$ & $0.874^{*}$ & 0.857 & $0.896^{*}$ & -0.627 & -0.489 & -0.447 \\
\hline
\end{tabular}

": Pearson correlation significant at $\mathrm{p}<0.05 ;{ }^{* *}$ : highly significant at $\mathrm{p}<0.01$; F.C: fecal coliforms; FS: Fecal Streptococci; E. coli: Escherichia coli; SS: Suspended Solid; COD: Chemical Oxygen Demand; BOD 5 : Biological Oxygen Demand; TKN: Total Kjeldhal Nitrogen; NH4 ${ }^{+}-\mathrm{N}$ ammonium; NO3 -N: Nitrate; TP: Total Phosphorus 
The correlation matrix revealed that $\mathrm{NO}_{3}{ }^{-}$ concentrations were negatively correlated with $E$. coli and the SS were found to positively correlate with fecal coliform concentration in dairy wastewater using an ecological treatment system (Morgan et al., 2008). Previous studies have also found positively correlate (at 111th OPD) with fecal coliform and SS $(r=0.85)$, but for fecal streptococci $\mathrm{r}=0.97$.

\section{DISCUSSION}

The aerated biofilter process appears to be well suited to the requirements of small wastewater treatment plant. The performance of the aerated biofilter process has been proven to be an effective process for treating domestic effluent. By using granular media, the aerated biofilter can be operated at high organic loading rate. In the present study, we interested to efficiency of aerobic treatment and to correlation between microbiological and physic-chemical parameters with $50 \mathrm{~cm}$ per day of organic loading rate applied in 8 sequences per day (pulsed rhythm).

The SS infiltrate deeper into this filter bed. This infiltration was result delaying surface clogging (Jedidi, and Abdennaceur, 1991). Suspended Solids reduction relatively high can be explained by clogging layer installation at $30 \mathrm{~cm}$ from surface filter bed. These improve performance purification of filter bed. The major of particulate pollution is retained at 30 and 60 $\mathrm{cm}$ of depth (position of first and second samples). The reduction of SS in filtering mass varied between 48 and $96 \%$, similar results also were found by Al-Turki (2010). The SS is more efficient following biomass installation. At outlet of column, treated wastewater does not exceed $24 \mathrm{mg} \mathrm{L}^{-1}$ of SS during OPD. Value conformed to standards Tunisian NT.106.02 rejection (30 mg L ${ }^{-1}$ ).

The biomass developed in filter bed increases with wastewater passage and favorite the contact with purifying microflora expressed by improvement performance purification COD from 66th OPD. Therefore, COD removal is improved by mechanical filtration expressed per SS reduction and increased wastewater passage.

COD removal is higher than $90 \mathrm{~cm}$ has $150 \mathrm{~cm}$ depth than that obtained at $30 \mathrm{~cm}$ of depth at $83 \mathrm{rd}$ OPD. The organic pollution elimination by the aerobic tested reactor with fixed biomass process is realized through mechanical filtration of SS in the first centimeters of filter bed and mineralization dissolved fraction by biological action (Rolland et al., 2009).
At outlet of column, BOD value did not exceed $30 \mathrm{mg}$ $\mathrm{L}^{-1}$ and is conformed to standards Tunisian NT.106.02 rejection.

During the first phase, we observed an important efficiency of $\mathrm{NH}_{4}{ }^{+}-\mathrm{N}$ reduction (99\%). This important elimination can be attributed to nitrifying microorganism's phenomenon, seeing as nitrate concentrations increase in different samplers. Nitrification efficiency is represented by high levels of nitrate $\left(\mathrm{NO}_{3}^{-}-\mathrm{N}\right)$ in treated wastewater. Nitrogen removal is independent of infiltration depth, $\mathrm{NO}_{3}{ }^{-} \mathrm{N}$ concentrations increased with depth. This effectiveness is maintained than conditions are favorable: no clogging, neutral $\mathrm{pH}$ to slightly alkaline and temperature ranged between 30 and $35^{\circ} \mathrm{C}$. Nitrification occurs gradually during rest phase. It results in a significant nitrate leaching with the first wastewater pulse whose concentration may well exceed the average rate of nitrogen reduced in wastewater. At the end of feeding phase, denitrification can occur simultaneously in filter bed become anoxic (Shabeeb et al., 2010).

During the first phase orthophosphates were more adsorbed at particles mineral surface than organic particles by Van der Waals forces. But with the biofilm development efficiency of phosphorus removal was negatively affected. Indeed biofilm reduced the contact and interaction between particles mineral and wastewater (Arias and Brix, 2005). Phosphorus removal is often low by filter sand; phosphorus concentration does not conform to standards Tunisian NT.106.02 rejection (0.05 mg L ${ }^{-1}$ ). Generally, siliceous sand (over $90 \%$ $\mathrm{SiO}_{2}$ ) did not show effectiveness phosphorus removal by adsorption and/or precipitation (Gougoussis, 1982).

With submersion and clogging installation, purification performance is improved. Indeed, decontamination evolution trend was not observed during OPD and may result to organic matter oxidation (Leverenz et al., 2009). Microorganism's removal improving gradually as oxygen demand can be satisfied reaching $210^{3} \mathrm{MPN} / 100 \mathrm{~mL}$ in treated wastewater in $60 \mathrm{~cm}$ of depth; with this condition treated wastewater characteristic is conformed to standards Tunisian NT.106.02 rejection (2000 fecal coliforms/100 mL). Torrens et al. (2009) showed the filters sands with a depth of $65 \mathrm{~cm}$ presented significant $(\mathrm{p}<0.05)$ higher removal of bacterial indicators than those of $25 \mathrm{~cm}$.

The microbial activity is affected by attachment and detachment processes due to the bacterial cells exchange between the suspended and attached biomass phases. Attachment processes include adsorption and physical straining on the soil matrix (Taylor and Jaffe, 1990). Detachment is the removal of attached-phase biomass and subsequent re-entrainment in soil matrix 
(Peyton and Characklis, 1993). The biofilms detachment did not affect effectiveness of treatment. This detachment may be beneficial because it can delay the clogging phenomenon.

With the progress of treatment considered reactor during OPD shows a decrease correlation between physicochemical and microbial characteristics. This agrees with results found by Surendraraj et al., 2009. At the beginning of OPD physicochemical parameter values are relatively high which causes microbial biomass development in particular increase fecal coliform, fecal streptococcus and $E$. coli. During treatment SS, COD, BOD 5 , TKN, $\mathrm{NH}_{4}{ }^{+}-\mathrm{N}, \mathrm{NO}_{3}{ }^{-}-\mathrm{N}$ and $\mathrm{P}$ decreases. This reduction has certainly an effect on indicators of fecal contamination growth. The reduction of BOD can result in the simultaneous reduction of coliform populations (Der Steen et al., 2000). Yathavamoorthi et al. (2010) measured a positive correlation of fecal coliform with BOD than with suspended solids and suggested that adsorption of fecal coliforms may be more important than sedimentation.

\section{CONCLUSION}

Results confirmed that the reactor tested is performed as an advanced treatment system for DBO, $\mathrm{COD}, \mathrm{SS}, \mathrm{NH}_{4}{ }^{+}-\mathrm{N}$ and $\mathrm{NO}_{3}{ }^{-}-\mathrm{N}$. Treated water analyzed showed an oxidation activity and an SS elimination mainly located in upper sand layers $(30 \mathrm{~cm}$ of depth). Despite that $96 \%$ of SS efficiency reduction, clogging is not achieved quickly that due to biofilm detachment phenomena. The siliceous sand does not show effectiveness vis-à-vis phosphorus removal. The removal of microbial indicators in the considered reactor depends on the depth of the filter and negatively correlated with $\mathrm{NO}_{3}{ }^{-}-\mathrm{N}$. Disinfection performances for the considered reactor are slightly higher than Tunisian standards. Tertiary treatment reduce microbial load, however chlore, ozone or UV disinfection should be considered.

\section{ACKNOWLEDGEMENT}

This study is one of the outputs of WATRELWARTEC Research Programme Contract, financed by Tunisian Ministry for Higher Education, Scientific Research and Technology. Thanks for WATREL experimental WWTP staff.

\section{REFERENCES}

AFNOR, 1992. Mise en œuvre des dispositifs d'assainissement http://www.afnor.org/content/download/15083/101 755

Al-Turki, A.I., 2010. Assessment of effluent quality of tertiary wastewater treatment plant at buraidah city and its reuse in irrigation. J. Applied Sci., 10: 1723-1731. DOI: 10.3923/jas.2010.1723.1731

Arias, C.A. and H. Brix, 2005. Phosphorus removal in constructed wetlands: can suitable alternative media be identified? Water Sci. Technol., 51: 267273. PMID: 16042267

Boller, M., 1997. Small wastewater treatment plants : A challenge to wastewater engineers. Wat. Sci. Technol., 35: 1-12. http://cat.inist.fr/?aModele $=$ afficheN\&cpsidt $=2732$ 149

Cha, W., H. Choi, J. Kin and J. Cho, 2005. Water quality dependence on the depth of the vadose zone in SAT-simulated soil columns. Water Sci. Technol., 5: 17-24. http://www.environmentalexpert.com/Files\%5C5302\%5Carticles\%5C $9781 \%$ 5CWaterqualitydependenceonthedepthofthevadose. pdf

Der Steen, P.V., A. Brenner, Y. Shabtai and G. Oron, 2000. The effect of environmental conditions on faecal coliform decay in post-treatment of UASB reactor effluent. Water Sci. Technol., 42: 111-118. http://www.iwaponline.com/wst/04210/wst042100 111.htm

Doan, H. and A. Lohi, 2009. Intermittent aeration in biological treatment of wastewater. Am. J. Eng. Applied Sci., 2: 260-267. DOI: 10.3844/ajeassp.2009.260.267

Gougoussis, C., 1982. Assainissement Individuel et Aptitude des Sols, à L'épuration des Effluents Domestiques. Editions du Bureau de recherches geologiques et minieres, Service geologique national, ISBN-10: 2715960204, pp: 354.

Guidelines for Managed Aquifer Recharge, 2009. Health and Environmental Risk Management. http://www.riskworld.com/nreports/1997/riskrpt/pdf/epajan.pdf

Ibrahim, R., M. Azmirruddin, M. Jabir, M.R. Ismail and M. Muhamad et al., 2010. Injection molding of titanium alloy implant for biomedical application using novel binder system based on palm oil derivatives. Am. J. Applied Sci., 7: 811-814. DOI: 10.3844/ajassp.2010.811.814

Jedidi, N. and H. Abdennaceur, 1991. Propriété physique des sols et pouvoir colmatant des eaux usées en fonction de leur degré de traitement. Cahiers-ORSTOM. Pédologie, 26: 3-10. http://cat.inist.fr/?aModele $=$ afficheN\&cpsidt $=5265710$ 
Leverenz, H.L., G. Tchobanoglous and J.L. Darby, 2009. Clogging in intermittently dosed sand filters used for wastewater treatment. Water Res., 43: 695-705. PMID: 19054539

Morgan, J.A., A.E. Hoet, T.E. Wittum, C.M. Monahan and J.F. Martin, 2008. Reduction of pathogen indicator organisms in dairy wastewater using an ecological treatment system. J. Environ. Qual., 37: 272-279. PMID: 18178901

Mediterranean Water Scarcity and Drought Report, 2006. Technical report on water scarcity and drought management in the mediterranean and the water framework directive. http://www.semide.net/media_server/files/o/p/JP_I _Report_WG_Water_Scarcity.pdf

Mutlu, I., 2009. Investigation of tribological properties of brake pads by using rice straw and rice husk dust. J. Applied Sci., 9: 377-381. http://www.cabdirect.org/abstracts/20093021627.ht $\mathrm{ml}$

National Sanitation Utility, 2009. Annual report 2009. http://www.onas.nat.tn/rapport/revue.pdf

Peyton, B.M. and W.G. Characklis, 1993. A statistical analysis of the effect of substrate utilization and shear stress on the kinetics of biofilm detachment, Biotechnol. Bioeng., 41: 728-735. PMID: 18609615

Rajeb, A.B., H. Kallali, N.B. Aissa, O. Bouzaiene and S. Jellali et al., 2009. Soil microbial growth and biofilm expansion assessment under wastewater infiltration percolation treatment process: Column experiments. Desalination, 246: 514-525. DOI: 10.1016/j.desal.2008.04.060

Rezaee, A., A. Khavanin and M. Ansari, 2008. Teatment of work camp wastewater using a sequencing batch reactor followed by a sand filter. Am. J. Environ. Sci., 4: 342-346. DOI: 10.3844/ajessp.2008.342.346
Rodier, J., 1978. L'analyse de l'eau. Eaux naturelles, eaux résiduaires, eaux de mer. 6th Édn., Dunod, Paris, ISBN: 2100496360, pp: 1383.

Rolland, L., P. Molle, A. Lienard, F. Bouteldja and A. Grasmick, 2009. Influence of the physical and mechanical characteristic of sands on the hydraulic and biological behaviors of sand filters. Desalination 248: 998-1007. DOI: 10.1016/j.desal.2008.10.016

Shabeeb, K.M., K.A. Sukkar, R.A. Azeez, N.J. Salah and A. Mummtas et al., 2010. A new development in biological process for wastewater treatment to produce renewable fuel. Am. J. Applied Sci., 7: 1400-1405. DOI: 10.3844/ajassp.2010.1400.1405

Surendraraj, A., K.H.S. Farvin, R. Yathavamoorthi and N. Thampuran, 2009. Enteric bacteria associated with farmed freshwater fish and its culture environment in Kerala, India. Res. J. Microbiol., 4:334-344. DOI: 10.3923/jm.2009.334.344

Taylor, S.W. and P.R. Jaffe, 1990. Substrate and biomass transport in a porous medium. Water Res., 26: 2182-2194. DOI: 10.1029/WR026i009p02181

Torrens, A., P. Molleb, C. Boutinb and M. Salgot, 2009. Removal of bacterial and viral indicators in vertical flow constructed wetlands and intermittent sand filters. Desalination, 246: 169-178. DOI: 10.1016/j.desal.2008.03.050

Yathavamoorthi, R., A. Surendraraj and K.H.S. Farvin, 2010. Enteric bacteria and water quality of freshwater prawn Macrobrachium rosenbergii (De Man) in culture environment from Kerala, India. J. Fish. Aquat. Sci., 5: 282-292. http://docsdrive.com/pdfs/academicjournals/jfas/00 00/17863-17863.pdf 